\title{
리스페리돈 복용 중 발생한 구획증후군을 동반한 횡문근 융해증 \\ 이민용 ${ }^{1}$, 강민구 ${ }^{1}$, 정광표 ${ }^{1}$, 김선형' , 전희원 ${ }^{1}$, 정선근 ${ }^{1,2,3,4}$ \\ '서울대학교병원 재활의학과, ${ }^{2}$ 서울대학교 의과대학 재활의학교실, ${ }^{3}$ 서울대학교 노화연구소, ${ }^{4}$ 서울대학교 의학연구원 류마티스연구소
}

\section{Delayed Onset Rhabdomyolysis and Compartment Syndrome in a Patient on Risperidone}

\author{
Min Yong Lee ${ }^{1}$, Min-Gu Kang ${ }^{1}$, Gwang-Pyo Jung ${ }^{1}$, Sun-Hyung Kim ${ }^{1}$, Hee Won Jeon', Sun G. Chung 1,2,3,4 \\ 'Department of Rehabilitation Medicine, Seoul National University Hospital, ${ }^{2}$ Department of Rehabilitation Medicine, \\ Seoul National University College of Medicine, ${ }^{3}$ Institute of Aging, Seoul National University, \\ ${ }^{4}$ Rheumatism Research Institute, Medical Research Center, Seoul National University, Seoul, Korea
}

\begin{abstract}
We report a case of rhabdomyolysis and acute compartment syndrome occurring after an hour of walking in a patient on risperidone for obsessive-compulsive disorder. He was diagnosed with anterior compartment syndrome in the right lower leg and underwent fasciotomies. As sequelae of compartment syndrome, right deep and superficial peroneal neuropathies were identified. In previous cases with risperidone associated rhabdomyolysis, the onset of rhabdomyolysis was mainly related to initiation or dosage increase of risperidone, while the patient of this case had been on a stable dosage of risperidone for more than 6 months. We suspect that genetic variations of 5-HT2A receptor may be related to this difference. Considering rhabdomyolysis and acute compartment syndrome demand earliest interventions to minimize irreversible sequelae, clinicians must have a high index of suspicion without dismissing the possibility of rhabdomyolysis in patients who have been taking risperidone on a stable dosage even for a long time.
\end{abstract}

Key Words: rhabdomyolysis, risperidone, compartment syndrome

\section{Introduction}

Risperidone is an atypical antipsychotic medication for psychiatric disorders. The adverse effects include

Received May 9, 2019

Revised (1st) July 15, 2019, (2nd) August 28, 2019

Accepted October 8, 2019

Corresponding Author: Sun G. Chung

Department of Rehabilitation Medicine, Seoul National University Hospital,

Seoul National University College of Medicine, 101 Daehak-ro, Jongno-gu,

Seoul 03080, Korea

Tel: 82-2-2072-3954, Fax: 82-2-743-7473, E-mail: suncg@snu.ac.kr extrapyramidal symptoms and increased prolactin levels. ${ }^{1}$ Rhabdomyolysis has been rarely reported. Rhabdomyolysis is a condition caused by muscle damage, leading to release of myoglobin and creatine kinase (CK) into the plasma. Although acute kidney injury is a well known severe complication of rhabdomyolysis, compartment syndrome is a severe potential complication. ${ }^{2}$ Compartment syndrome is a disease resulting from myonecrosis within a tight fascial compartment, raising intra-compartmental pressure excessively to compromise local blood flow. The complications in-
Copyright $\odot$ by Korean Association of EMG Electrodiagnostic Medicine
This is an Open Aocess article distributed under the terms of the Creative Commons Attribution Non-Commercial License (http:// creativecommons.org/licenses/by-nc/4.0) which permits unrestricted non-commercial use, distribution, and reproduction in any medium, provided the original work is properly cited. 
clude loss of limb, deformity, and neural injury. ${ }^{3}$

Several cases of risperidone associated rhabdomyolysis have been reported. ${ }^{4}$ In most cases, the onset of rhabdomyolysis was mainly related to initiation or dosage increase of risperidone. However, we have recently experienced an unusual case of risperidone associated rhabdomyolysis, occurring without preceding changes of medications or dosages. We report the case presented as an occurrence of rhabdomyolysis and compartment syndrome after an hour of walking in a patient on a stable dosage of risperidone for more than 6 months.

\section{Case Report}

A 28-year-old male patient with obsessive-compulsive disorder (OCD) visited the emergency department with right lower leg pain. Besides OCD, he had an unremarkable medical history. His medications included daily dosages of risperidone $3 \mathrm{mg}$, fluoxetine $80 \mathrm{mg}$, sertraline $400 \mathrm{mg}$, clonazepam $0.5 \mathrm{mg}$, propranolol $20 \mathrm{mg}$, and clomipramine $25 \mathrm{mg}$. Risperidone, fluoxetine, clonazepam, and propranolol were initiated 10 months ago. Sertraline was added 6 months ago. Clomipramine was added 2 months prior and the initial dosage had been maintained until recently. All medications except clomipramine had been taken on the same dosages for the past 6 months.
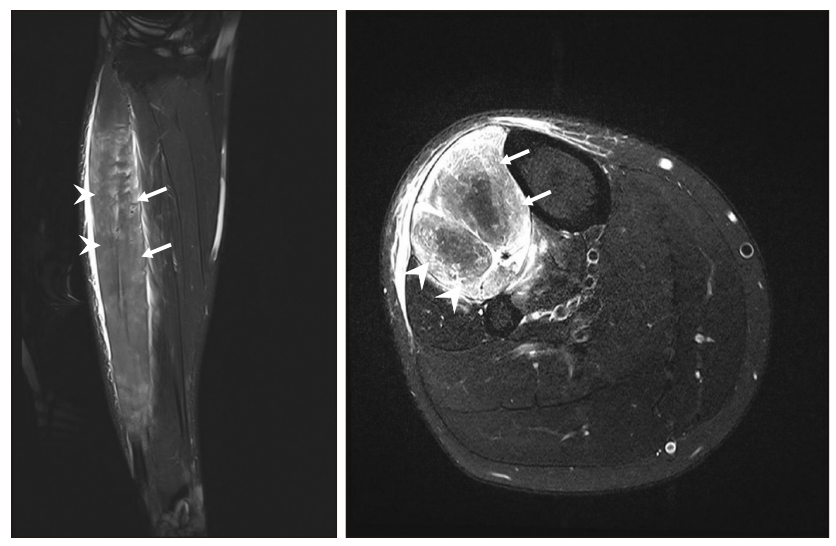

Fig. 1. T2-weighted coronal (left) and axial (right) MR images of the right lower leg demonstrate enhancements of the tibialis anterior (arrows) and extensor digitorum longus (arrowheads).
He noticed sudden pain with warmness that started 2 days ago in the right anterior lower leg, but denied any trauma. The pain was developed while he was walking for exercise on level ground at an average speed of $4 \mathrm{~km} /$ hour for an hour. He denied any unusual precipitating factors, such as prolonged immobilization, fatigue, or dehydration before the onset. He used to be a social drinker, but he quit it two years ago and had no history of herbal supplements. He used to walk 30 to 60 minutes a day and has not been engaged in any other exercise activities.

On the manual muscle test in his lower extremities, his hip flexors and knee extensors are intact, and his both ankle dorsiflexors, 1st toe extensors and ankle plantar flexors are $1 / 5$ on the right/left side. His CK was 12,012 IU/L (normal range, 20 270 IU/L), AST and ALT were $430 \mathrm{IU} / \mathrm{L}$ and $412 \mathrm{IU} / \mathrm{L}$ (normal range, 1 40 IU/L), blood urea nitrogen was $12 \mathrm{mg} / \mathrm{dL}$ (normal range, $10 \sim 26 \mathrm{mg} / \mathrm{dL}$ ) and creatinine was $1.07 \mathrm{mg} / \mathrm{dL}$ (normal range, 0.7 1.4 mg/dL). Under the impression of rhabdomyolysis, magnetic resonance (MR) imaging was done. The MR images of the right lower leg showed marked swelling of the tibialis anterior (TA) and extensor digitorum longus with edematous changes in the perifascial tissues (Fig. 1). He was diagnosed with 'acute compartment syndrome' and underwent fasciotomies (Fig. 2).

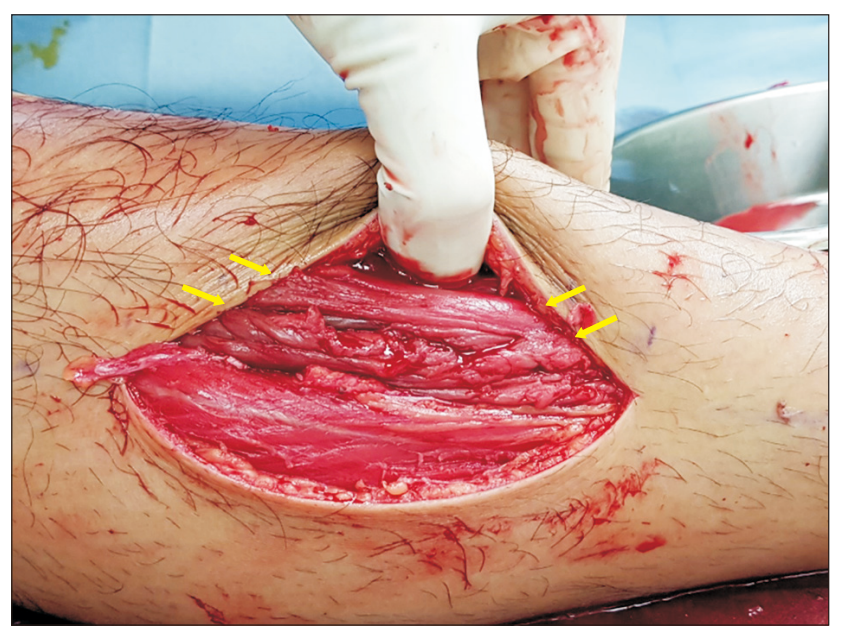

Fig. 2. An urgent fasciotomy with incision of the right lower leg was performed. The anterior compartment muscles were necrotic (arrows). 
Table 1. Results of Sensory Nerve Conduction Studies

\begin{tabular}{|c|c|c|c|c|c|c|c|c|c|c|}
\hline \multirow{3}{*}{ Nerve } & \multirow{3}{*}{$\begin{array}{l}\text { Stimulation } \\
\text { site }\end{array}$} & \multirow{3}{*}{ Recording site } & \multicolumn{4}{|c|}{ Right } & \multicolumn{4}{|c|}{ Left } \\
\hline & & & \multicolumn{2}{|c|}{ Initial (POD $1 \mathrm{mo}$ ) } & \multicolumn{2}{|c|}{ Follow-up (POD 9 mo) } & \multicolumn{2}{|c|}{ Initial (POD $1 \mathrm{mo}$ ) } & \multicolumn{2}{|c|}{ Follow-up (POD 9 mo) } \\
\hline & & & $\begin{array}{l}\text { Onset Lat } \\
(\mathrm{ms})\end{array}$ & $\begin{array}{l}\text { Amp } \\
(\mu V)\end{array}$ & $\begin{array}{l}\text { Onset Lat } \\
\text { (ms) }\end{array}$ & $\begin{array}{l}\text { Amp } \\
(\mu \mathrm{V})\end{array}$ & $\begin{array}{l}\text { Onset Lat } \\
\text { (ms) }\end{array}$ & $\begin{array}{l}\text { Amp } \\
(\mu \mathrm{V})\end{array}$ & $\begin{array}{l}\text { Onset Lat } \\
(\mathrm{ms})\end{array}$ & $\begin{array}{l}\text { Amp } \\
(\mu \mathrm{V})\end{array}$ \\
\hline Superficial peroneal & Below FH & Foot dorsum & NR & NR & 2.4 & 3.7 & 2.45 & 12.9 & 2.45 & 13.1 \\
\hline Deep peroneal & Ankle & 1st web space of foot & $N R$ & NR & $N R$ & $N R$ & 2.29 & 6.0 & 2.14 & 12.7 \\
\hline Sural & Calf & Lateral malleolus & 2.76 & 13.2 & 2.55 & 11.1 & 2.50 & 11.1 & 2.71 & 8.3 \\
\hline
\end{tabular}

POD: postoperative day, Lat: latency, Amp: amplitude, NR: no response, FH: fibular head

Table 2. Results of Motor Nerve Conduction Studies

\begin{tabular}{|c|c|c|c|c|c|c|c|c|c|c|c|c|c|}
\hline \multirow{3}{*}{$\begin{array}{c}\text { Nerve } \\
\text { electrode }\end{array}$} & \multirow{3}{*}{$\begin{array}{l}\text { Stimulation } \\
\text { site }\end{array}$} & \multicolumn{6}{|c|}{ Right } & \multicolumn{6}{|c|}{ Left } \\
\hline & & \multicolumn{3}{|c|}{ Initial (POD 1 mo) } & \multicolumn{3}{|c|}{ Follow-up (POD 9 mo) } & \multicolumn{3}{|c|}{ Initial (POD 1 mo) } & \multicolumn{3}{|c|}{ Follow-up (POD 9 mo) } \\
\hline & & $\begin{array}{c}\text { Onset } \\
\text { Lat (ms) }\end{array}$ & $\begin{array}{l}\text { Amp } \\
(m V)\end{array}$ & $\begin{array}{c}\mathrm{CV} \\
(\mathrm{m} / \mathrm{s})\end{array}$ & $\begin{array}{c}\text { Onset } \\
\text { Lat (ms) }\end{array}$ & $\begin{array}{l}\text { Amp } \\
(m V)\end{array}$ & $\begin{array}{c}\mathrm{CV} \\
(\mathrm{m} / \mathrm{s})\end{array}$ & $\begin{array}{c}\text { Onset } \\
\text { Lat (ms) }\end{array}$ & $\begin{array}{l}\text { Amp } \\
(\mathrm{mV})\end{array}$ & $\begin{array}{c}\mathrm{CV} \\
(\mathrm{m} / \mathrm{s})\end{array}$ & $\begin{array}{c}\text { Onset } \\
\text { Lat (ms) }\end{array}$ & $\begin{array}{l}\text { Amp } \\
(m V)\end{array}$ & $\begin{array}{c}\mathrm{CV} \\
(\mathrm{m} / \mathrm{s})\end{array}$ \\
\hline \multirow[t]{2}{*}{ Peroneal-EDB } & Ankle & NR & NR & - & NR & NR & - & 3.59 & 4.1 & - & 3.23 & 3.8 & - \\
\hline & Below FH & NR & NR & NR & $N R$ & NR & NR & 10.83 & 3.4 & 47.0 & 10.57 & 3.8 & 47.7 \\
\hline \multirow[t]{2}{*}{ Peroneal-TA } & Below FH & 2.60 & 1.7 & - & 3.13 & 2.4 & - & 2.76 & 7.4 & - & 2.76 & 8.0 & - \\
\hline & Above FH & 4.27 & 1.5 & 54.0 & 3.96 & 2.4 & 48.0 & 4.38 & 7.1 & 55.7 & 3.96 & 7.9 & 50.1 \\
\hline Peroneal-PL & Below FH & 3.85 & 2.6 & - & 4.11 & 3.7 & - & 2.84 & 5.8 & - & 3.96 & 6.1 & - \\
\hline \multirow[t]{2}{*}{ Tibial-AH } & Ankle & 4.06 & 17.0 & & 3.28 & 18.0 & & 4.27 & 10.4 & & 3.02 & 13.6 & \\
\hline & Knee & 12.6 & 12.4 & 46.8 & 11.61 & 15.9 & 52.8 & 12.81 & 7.8 & 49.2 & 11.46 & 11.0 & 51.0 \\
\hline
\end{tabular}

POD: postoperative day, Lat: latency, Amp: amplitude, CV: conduction velocity, EDB: extensor digitorum brevis, TA: tibialis anterior, PL: peroneus longus, AH: abductor halluces, FH: fibular head

After the surgery, he began walking on crutches. The CK was gradually decreased. He was referred to a psychiatrist, who recommended to titrate risperidone from 3 to $2 \mathrm{mg} /$ day. After 3 months, the dosage was reduced to $1 \mathrm{mg} /$ day. The sertraline was reduced from 400 to $200 \mathrm{mg} /$ day.

To evaluate nerve injury, an electrodiagnostic study was conducted 4 weeks after surgery. Before the study, we found that the right ankle plantar flexors were recovered to normal, but the ankle dorsiflexors and 1st toe extensors were stationary. Sensory nerve conduction studies (NCS) showed no response in the right superficial and deep peroneal nerves (Table 1). In motor NCS, a compound motor action potential (CMAP) in the right TA was decreased and a CMAP of extensor digitorum brevis (EDB) was not observed. The CMAP of the right peroneus longus (PL) was decreased (Table 2). In electromyography (EMG), the right $\mathrm{EDB}$ and extensor hallucis longus showed abnormal spontaneous activities and no activity of motor unit action poten-
Table 3. Needle Electromyographic Examination (POD 1 month)

\begin{tabular}{lcccc}
\hline \hline \multicolumn{1}{c}{ Muscle } & $\begin{array}{c}\text { Insertional } \\
\text { activity }\end{array}$ & Fibrillation & $\begin{array}{c}\text { Positive } \\
\text { sharp wave }\end{array}$ & $\begin{array}{c}\text { Interference } \\
\text { pattern }\end{array}$ \\
\hline Rt. EDB & Normal & $3+$ & $3+$ & No activity \\
Rt. EHL & Normal & $1+$ & $1+$ & No activity \\
Rt. TA & Normal & $3+$ & $3+$ & Reduced \\
Rt. PL & Normal & 0 & 0 & Reduced \\
Rt. Bic Fem(S) & Normal & 0 & 0 & Normal \\
Rt. Medial GCM & Normal & 0 & 0 & Normal \\
\hline
\end{tabular}

POD: postoperative day, EDB: extensor digitorum brevis, EHL: extensor hallucis longus, TA: tibialis anterior, PL: peroneus longus, Bic Fem(S): Biceps femoris short head, GCM: gastrocnemius

tial. The right TA showed abnormal spontaneous activities and a reduced interference pattern. However, unlike the muscles innervated by the deep peroneal nerve, the right PL showed reduced interference pattern with no abnormal spontaneous activities (Table 3). The patient was diagnosed with right deep peroneal and superficial peroneal neuropathy. After 8 months, the electrodiagnostic study was followed up. Compared previous study, right superficial peroneal neuropathy was well recovered, but right deep peroneal 
neuropathy was stationary.

Nine months after the surgery, his right ankle dorsiflexors were still not recovered. However, he could walk alone without assist or aid, although he was uncomfortable.

\section{Discussion}

In the present case of spontaneous rhabdomyolysis without any histories of recent trauma or excessive exercise, there was no evidence of any other causes, such as infection, prolonged immobilization, and statin medication. Therefore, it is reasonable to point out risperidone as the most probable cause for rhabdomyolysis. Although some cases have reported that rhabdomyolysis could be developed by SSRI alone, ${ }^{5}$ in that cases, there were preceding factors, such as an excessive exercise, unlike the cases of risperidone associated rhabdomyolysis.

Risperidone is known as a potential risk factor of rhabdomyolysis. One of the known mechanisms of antipsychotics associated rhabdomyolysis is that antipsychotics may increase membrane permeability of skeletal muscle cells, through blockade of 5-HT2A receptors. It can increase the intramuscular calcium level, leading to mitochondrial dysfunction and muscle cell necrosis. $^{6}$

Some cases with SSRI associated rhabdomyolysis have been reported. ${ }^{5}$ Accumulated serotonin by SSRI in skeletal muscle cells may predispose to intramuscular calcium accumulation. Therefore, the combination of risperidone and SSRIs can have synergic effects on the intramuscular calcium accumulation, leading to muscle damage. ${ }^{7}$ Additionally, because risperidone is metabolized by the cytochrome P450 2D6 inhibited by fluoxetine and sertraline, a combination of risperidone, fluoxetine and sertraline can increase blood levels of risperidone, ${ }^{8}$ which could be another synergic mechanism to incur rhabdomyolysis.

From previous cases with risperidone associated rhabdomyolysis retrieved through PubMed search, certain common characteristics are found as follows. Firstly, the onset of rhabdomyolysis was mainly related to initiation or dosage increase of risperidone. Secondly, there was a co-administration of other medications, such as other antipsychotics and benzodiazepines in most cases. Thirdly, the dosage range of risperidone was between 1 and $8 \mathrm{mg} /$ day, with one over-dose case (96 mg).

Comparing the above characteristics with the present case, the co-administered drugs in our patient, benzodiazepine, SSRI, and tricyclic antidepressant, were relatively common in risperidone-related rhabdomyolysis. His dosage of risperidone, $3 \mathrm{mg} /$ day, was significantly lower than the general dosage of risperidone, 4 16 mg/day and comparably lower than the reported dosages in rhabdomyolysis cases, 1 and 8 $\mathrm{mg} /$ day.

The key difference is that the patient in this case had been on a stable regimen in terms of dosage of risperidone and co-administered medications, for more than 6 months. We suspect that this discrepancy of onset is due to the difference in individual responses to risperidone. Lane et al. suggested that polymorphism in the 5-HT2A receptor gene may be associated with risperidone treatment response. ${ }^{9}$ Although it is not certain whether the polymorphism affects cellular responses to the muscle of risperidone, certain genetic variations may be related to the vulnerability to risperidone-associated rhabdomyolysis. If the genetic variations are found, genotyping of 5-HT2A receptor will have predictive values for the development of risperidone-associated rhabdomyolysis. However, it is uncertain whether some genetic factors were associated with risperidone-associated rhabdomyolysis in this case, because the genetic test of 5-HT2A receptor was not performed.

The present case would be informative to clinicians because rhabdomyolysis and compartment syndrome demand earliest interventions to minimize irreversible sequelae. It advises that a clinician must have a high index of suspicion without dismissing the possibility 
of rhabdomyolysis in patients who have been taking risperidone on a stable dosage for a long time. In addition, because even low-intensity activity can develop rhabdomyolysis, a clinician must inform the patients of potential risk factors and initial presentations of rhabdomyolysis.

\section{References}

1. Look ML, Boo YL, Chin PW, Hoo FK: Risperidone-associated rhabdomyolysis without neuroleptic malignant syndrome: a case report. J Clin Psychopharmacol 2017: 37:105-106

2. Sauret JM, Marinides G, Wang GK: Rhabdomyolysis. Am Fam Physician 2002: 65

3. Whitesides TE, Heckman MM: Acute compartment syndrome: update on diagnosis and treatment. J Am Acad Orthop Surg 1996: 4: 209-218

4. Packard K, Price P, Hanson A: Antipsychotic use and the risk of rhabdomyolysis. J Pharm Pract 2014: 27: 501-512

5. Snyder M, Kish T: Sertraline-Induced Rhabdomyolysis: A Case Report and Literature Review. Am J Ther 2016: 23: e561-565

6. Meltzer HY, Cola PA, Parsa M: Marked elevations of serum creatine kinase activity associated with antipsychotic drug treatment. Neuropsychopharmacology 1996: 15: 395

7. Hsu YC, Yeh YW: Multidrug overdose-induced myoclonus complicated by rhabdomyolysis: possible role and mechanism of muscle toxicity of risperidone. J Clin Pharm Ther 2014: 39: 698-700

8. Lynch T, Price A: The effect of cytochrome P450 metabolism on drug response, interactions, and adverse effects, Am Fam Physician 2007: 76: 391-396

9. Lane HY, Chang YC, Chiu CC, Chen ML, Hsieh MH, Chang W-H: Association of risperidone treatment response with a polymorphism in the 5-HT2A receptor gene. Am J Psychiatry 2002: 159: 1593-1595 